\title{
Effect of Initial Cytoreductive Nephrectomy with Target Therapy versus Target Therapy Alone in Metastatic Renal Cell Carcinoma: A Single Institutional Study
}

\author{
Rasha Mohamed Abdel Latif ${ }^{1}$, Kamel Farag Selim ${ }^{2}$ \\ ${ }^{1}$ Clinical Oncology and Nuclear Medicine Department, Faculty of Medicine, Mansoura University, Mansoura, Egypt \\ ${ }^{2}$ Oncology Center, Faculty of Medicine, Mansoura University, Mansoura, Egypt
}

\section{ARTICLE INFO}

Received : 07 April 2019

Reviewed: 09 April 2019

Accepted : 27 May 2019

\section{Keywords:}

cytoreductive nephrectomy, metastatic renal carcinoma, target therapy

\begin{abstract}
A BSTRACT
Background: The metastatic renal cell carcinoma (mRCC) patients treated with upfront cytoreductive nephrectomy (CN) combined with immunotherapy results in overall survival (OS) improvement. It is unclear whether mRCC patients treated with target therapy will also benefit from $\mathrm{CN}$. The aim of the study was to identify the benefit of upfront CN followed by targeted therapy (TTs) versus TTs alone on OS of patients with $\mathrm{mRCC}$, and to evaluate pre-operative variables for selection of patients who would benefit from $\mathrm{CN}$, and also the response rate (RR) and the progression-free survival (PFS).
\end{abstract}

Methods: A retrospective study was performed in our Department on patients diagnosed with mRCC within the period of January 2013 to April 2018. Data that were collected included patients and tumor characteristics. Patients were divided into two groups: 1 ) received upfront $\mathrm{CN}$ followed by TTs, and the 2 ) one treated with TTs alone. Survival analysis was performed using Kaplan-Meier method, univariate analysis with log-rank test was used to estimate predictors of survival in the CN group, and Cox regression was used for multivariate analysis.

Results: The median OS of all patients was 14 months, and was 19 and 10.5 months in $\mathrm{CN}$ and non-CN respectively with significant difference $(P<0.001)$. Lower hemoglobin level $(P=0.012)$, high neutrophil count $(P<0.001)$, low albumin level $(P=0.006)$, number of metastatic sites $\geq 3 \quad(P<0.001)$, and patients with number of risk factors $\geq 3 \quad(P<0.001)$ have a negative impact on $\mathrm{OS}$ in $\mathrm{CN}$ group.

Conclusions: Upfront CN before TTs in mRCC carries better survival than TTs alone. Five pre-operative variables (i.e. hemoglobin level, neutrophil count, albumin level, number of metastatic sites, and number of risk factors) were identified as suitable for selection of patients who will benefit from $\mathrm{CN}$.

\section{INTRODUCTION}

Renal cell carcinoma (RCC) is the commonest malignancy of kidney representing about 90\% [1]. Incidence of RCC varies according to the country as it is higher in Europe and North America than Asia and South America [2]. In Egypt, kidney cancer presented in $1.8 / 100000$ in male and $1.1 / 100000$ in female of all ages, and the numbers increase in older age above 55 years [3].

Around $20 \%$ of RCC is presented as metastatic disease synchronous at diagnosis with primary tumor and carries poor prognosis [4, 5]. Treatment of metastatic renal cell carcinoma (mRCC) was a question of the challenge to researchers, especially in absence of effective chemotherapeutic agents and role of radiation in palliation of metastasis, so they tried to find the optimal treatment for these categories.

Cytoreductive nephrectomy ( $\mathrm{CN}$ ) was considered as an important part in the management of $\mathrm{mRCC}$ as a palliative tool in relieving bleeding, pain, compression symptoms, and it is proven to improve overall survival (OS) when being used before immunotherapy, as immunotherapy was the most effective systemic treatment at this time [6-8]. Since the Food and Drug Administration (FDA) has approved target therapy in 
treatment of mRCC since 2005, several agents of target therapies were used in aiming to reach the best response and survival of $\mathrm{mRCC}$ patients. Target therapy directed to vascular endothelial growth factor and mammalian target of rapamycin (mTOR) have become the treatment of choice for mRCC [9-11].

Researchers compared different target therapies either in comparison to each other or to placebo, and they recorded acceptable results regarding survival [1218]. After that, the role of $\mathrm{CN}$ became controversial. Studies proved that $\mathrm{CN}$ reduced risk of death in combination with TTs more than those treated with TTs alone $[19,20]$.

With the improvement of overall survival (OS) with the addition of CN to TTs in $\mathrm{MRCC}$, some studies reported that selected patients with certain risk factors may benefit from $\mathrm{CN}$ than others. These risk factors consist of poor performance status (PS), high c-reactive protein, hemoglobin $(\mathrm{Hg})$ less than normal, high neutrophil-lymphocyte ratio, sarcomatoid dedifferentiation, body mass index (BMI), LDH, serum creatinine, and number of metastatic sites. Patients with 0-2 risk factors only get benefit from upfront $\mathrm{CN}$ as regard OS [21-25]. On the other hands, there were studies that reported no benefit of upfront $\mathrm{CN}$ in comparison to TTs alone [26, 27].

In this study, we try to evaluate the survival benefit of $\mathrm{CN}$ upfront to TTs versus target therapy alone as the primary endpoint. We also try to evaluate risk factors associated with improved survival treated with upfront $\mathrm{CN}$, progression-free survival (PFS) and response rate $(\mathrm{RR})$ as the secondary endpoint.

\section{METHODS}

\section{Patients}

This study obtained ethical approval from the Institutional Review Board of Mansoura Faculty of Medicine (IRB-MFM). This is a retrospective study performed on patients diagnosed with metastatic renal cell carcinoma (mRCC) who attended the Department of Clinical Oncology \& Nuclear Medicine, Mansoura University Hospital, Mansoura, Egypt, within the period of January 2013 to April 2018.

The patients data were collected from files and we recorded age, sex, presentation, performance status, $T$ stage, $\mathrm{N}$ stage, $\mathrm{Hg}$, neutrophil count, platelet count, serum calcium, lactate dehydrogenase (LDH) if reported, albumin, side and size of primary tumor, histology, pathological variant, number and sites of metastasis, time of diagnosis to treatment, surgery performed, and type of used target therapies (TTS). Staging procedures included chest radiography, computed tomography (CT) of abdomen and pelvis, bone scan, CT of the chest and/ or brain performed if indicated.
Inclusion criteria including age $\geq 18$ years, pathologically proven metastatic renal cell carcinoma, metastasis diagnosed radiologically, patients received target therapy (either alone or proceeded by CN). As for exclusion criteria including non-clear renal cell carcinoma, synchronous with other malignancies, received systemic chemotherapy, not evaluated during or after treatment, and patients refused target therapy.

\section{Treatment modalities}

Surgery was performed if indicated and feasible, the biopsy was taken for pathological confirmation either from the primary or metastatic lesion. Patients were treated with either TTs alone or TTs with CN. Target therapies consisted of $50 \mathrm{mg}$ sunitinib once daily for 28 days and discontinued for 14 days, continued to be replaced with everolimus tablet once daily or $800 \mathrm{mg} / \mathrm{m} 2$ pazopanib once daily.

\section{Toxicity assessment}

Median follow up period was 13 months (range 235 months). Toxicity was assessed according to Common Terminology Criteria for Adverse Events version 3.0. If toxicity was registered, treatment would be discontinued until recovery or return to grade 1 or less with a reduction of dose. If toxicity continued for more than 14 days or after 2 reductions of dose, treatment was stopped. Patients received treatment until progression, toxicity, or death.

\section{Survival outcomes and response assessment}

The response was assessed according to the Response Evaluation Criteria in Solid Tumors version 1.0. Complete response (CR) was defined as disappearance of all target, partial response (PR) as at least a $30 \%$ decrease in the sum of the longest diameter (LD) of target lesions, stable disease (SD) as neither sufficient shrinkage to qualify for $P R$ nor sufficient increase to qualify for progressive disease (PD), and PD as at least a $20 \%$ increase in the sum of the LD of target lesions. Data was recorded since the treatment started or the appearance of one or more new lesions. Overall survival (OS) was measured from the time of diagnosis of metastasis until loss of follow up or death. Progression-free survival (PFS) was measured from the time of diagnosis of metastasis until progression, the appearance of new lesions, end of follow up, and/or death.

Patients were followed every 6 weeks during the 24-week treatment and every 12 weeks after the 24week treatment. The evaluation was performed with computerized tomography (CT) of abdomen and pelvis, and chest $\mathrm{CT}$, bone scan if indicated. 


\section{Statistical analysis}

Data analysis was performed using SPSS version 20.0. The PFS was defined from the time of metastases being diagnosed until disease progression, death, or loss to follow up. Overall survival was calculated from the date of diagnosis to date of death, or loss of follow up.

Qualitative data were presented as number and percent. Non-parametric data were presented as minmax and median. Survival analysis was calculated using Kaplan-Meier method, and the survival rates were compared by the log-rank test. Comparisons between patient groups were performed by the Chi-square test. Multivariate analysis was performed with Cox regression model to estimate the prognostic significance of pre-operative characteristics in predicting OS in patients treated with upfront $\mathrm{CN}$ followed by targeted therapy. Only variables with $\mathrm{P} \leq 0.05$ in univariate analysis were included in multivariate analysis. All statistical tests were 2 sided with $\mathrm{P} \leq 0.05$ considered as significant.

\section{RESULTS}

\section{Patients Characteristics}

Table 1 shows the clinicopathologic data of the patients. The median age of all patients was 55 years (range $20-76$ years), with $67.6 \%$ in age group $>50$ years. Most of the patients were male $(70.3 \%)$, with male to female ratio of 2.4:1. Twenty-one patients (56.8\%) attended with PS 1 , with $86.5 \%$ associated with comorbidities, mostly in the form of hypertension and diabetes mellitus. Local symptoms were the commonest presentation which found in 25 patients (67.6\%).

Median BMI was 27, 31 patients (83.8\%) were with $\mathrm{BMI}$ in normal range of $19-30 \mathrm{~kg} / \mathrm{m} 2$ and $6(16.2 \%)$ were $>30 \mathrm{~kg} / \mathrm{m} 2$. The T2 was the most common stage diagnosed which was found in 19 patients (51.4\%), and 18 patients were $\mathrm{N}+(48.6 \%)$. The median size of the tumor was $9 \mathrm{~cm}$. Rhabdoid and sarcomatoid features were presented only in 4 patients $(10.8 \%)$. Bone was the most common site of metastasis followed by lung (64.9\% and $45.9 \%$, respectively).

The $\mathrm{Hg}$, platelet count, neutrophil count, LDH, albumin level were abnormal in 35.1\%, 10.8\%, 40.5\%, $16.2 \%$, and $21.6 \%$ respectively. Corrected serum calcium was not recorded.

Twenty-five patients were treated with $\mathrm{CN}$ followed by target therapy, and 12 patients were treated with TTs only (non-cytoreductive nephrectomy; NCN group). Sutent was the most used TTs (59.5\%). Thirteen patients (35.1\%) were with $\leq 3$ risk factors and 24 (64.9\%) were diagnosed with $>3$ risk factors.

There was significant statistical difference between $\mathrm{CN}$ and NCN groups in terms of platelet level, T stage, N stage, Rh and sarcomatoid features, lung metastases, and number of risk factors, but other factors presented no statistical difference between the two groups.

Table 1. Patient's characteristics

\begin{tabular}{|c|c|c|}
\hline Characteristics & $\begin{array}{l}\text { Cytoreductive } \\
\mathrm{N}=25(67,6 \%)\end{array}$ & $\begin{array}{l}\text { Non-cytoreductive } \\
\mathrm{N}=12(32,4 \%)\end{array}$ \\
\hline \multicolumn{3}{|l|}{ Age } \\
\hline Median (range) & $54(20-76)$ & $58(35-72)$ \\
\hline \multicolumn{3}{|l|}{ Sex } \\
\hline Male & $16(64)$ & $10(83.3)$ \\
\hline Female & $9(36)$ & $2(16.7)$ \\
\hline \multicolumn{3}{|l|}{ PS } \\
\hline 1 & $17(68)$ & $4(33.3)$ \\
\hline 2 & $7(28)$ & $5(41.7)$ \\
\hline 3 & $1(4)$ & $3(25)$ \\
\hline \multicolumn{3}{|l|}{ Comorbidities } \\
\hline Yes & $3(12)$ & $2(16.7)$ \\
\hline No & $22(88)$ & $10(83.3)$ \\
\hline \multicolumn{3}{|l|}{ Presentation } \\
\hline Local & $16(64)$ & $9(75)$ \\
\hline Systemic & $9(360$ & $3(25)$ \\
\hline \multicolumn{3}{|l|}{ BMI } \\
\hline Median & 27 & 27.5 \\
\hline \multicolumn{3}{|l|}{$\mathrm{Hg}$} \\
\hline $\mathrm{N}$ & $18(72)$ & $6(50)$ \\
\hline$<\mathrm{N}$ & $7(28)$ & $6(50)$ \\
\hline \multicolumn{3}{|l|}{ Neutrophil } \\
\hline $\mathrm{N}$ & $17(68)$ & $5(58.3)$ \\
\hline$>\mathrm{N}$ & $8(32)$ & 7 (41.7) \\
\hline \multicolumn{3}{|l|}{ Plat } \\
\hline $\mathrm{N}$ & $24(96)$ & $9(75)$ \\
\hline$>\mathrm{N}$ & $1(4)$ & $3(25)$ \\
\hline \multicolumn{3}{|l|}{ Alb } \\
\hline $\mathrm{N}$ & $21(84)$ & $8(66.7)$ \\
\hline$<N$ & $4(16)$ & $4(33.3)$ \\
\hline \multicolumn{3}{|l|}{ LDH } \\
\hline Not assessed & $20(80)$ & $8(66.7)$ \\
\hline$<1.5 U L \mathrm{~N}$ & $2(8)$ & $1(8.3)$ \\
\hline$>1.5$ ULN & $3(12)$ & $3(25)$ \\
\hline \multicolumn{3}{|l|}{ Side } \\
\hline Rt & $5(20)$ & $5(58.3)$ \\
\hline $\mathrm{Lt}$ & $20(80)$ & 7 (41.7) \\
\hline \multicolumn{3}{|l|}{ T stage } \\
\hline $\mathrm{T} 1$ & $0(0)$ & $1(8.3)$ \\
\hline $\mathrm{T} 2$ & $16(64)$ & $3(25)$ \\
\hline T3 & $8(32)$ & $5(41.7)$ \\
\hline $\mathrm{T} 4$ & $1(4)$ & $3(25)$ \\
\hline \multicolumn{3}{|l|}{ N stage } \\
\hline NO & $16(64)$ & $3(25)$ \\
\hline $\mathrm{N}+$ & $9(36)$ & $9(75)$ \\
\hline \multicolumn{3}{|l|}{ RH or sarcomatoid } \\
\hline No & $24(96)$ & $9(75)$ \\
\hline Yes & $1(4)$ & $3(25)$ \\
\hline $\begin{array}{l}\text { Size of tumor } \\
\text { Median }\end{array}$ & 2 & 2 \\
\hline
\end{tabular}

PS: performance status, BMI: body mass index, $\mathrm{Hg}$ : hemoglobin, $\mathrm{N}$ : normal, plat: platelet, alb: albumin, LDH: lactate dehydrogenase; Rt: right, Lt: left, RH: rhabdoid. 
Table 1. Patient's characteristics (Continue)

\begin{tabular}{|c|c|c|}
\hline Characteristics & $\begin{array}{l}\text { Cytoreductive } \\
\mathrm{N}=25(67,6 \%)\end{array}$ & $\begin{array}{l}\text { Non-cytoreductive } \\
\mathrm{N}=12(32,4 \%)\end{array}$ \\
\hline \multicolumn{3}{|l|}{ Bone mets } \\
\hline Yes & $17(68)$ & $7(58.3)$ \\
\hline No & $8(32)$ & $5(41.7)$ \\
\hline \multicolumn{3}{|l|}{ Liver mets } \\
\hline Yes & $5(20)$ & $3(25)$ \\
\hline No & $20(80)$ & $9(75)$ \\
\hline \multicolumn{3}{|l|}{ Lung mets } \\
\hline Yes & $8(32)$ & $9(75)$ \\
\hline No & $17(68)$ & $3(25)$ \\
\hline \multicolumn{3}{|l|}{ No. of mets } \\
\hline$<3$ & $9(36)$ & $1(8.3)$ \\
\hline$\geq 3$ & $16(64)$ & $11(91.7)$ \\
\hline \multicolumn{3}{|l|}{ No. of risks } \\
\hline Median & 3 & 5.5 \\
\hline \multicolumn{3}{|l|}{ TTs } \\
\hline Sutent & $15(60)$ & $7(58.3)$ \\
\hline Affinitor & $6(24)$ & $2(16.7)$ \\
\hline Votriant & $4(16)$ & $3(25)$ \\
\hline
\end{tabular}

\section{Outcomes}

The median OS of all patients was 14 months (range 6-38 months), OS rates at 12 and 24 months were $96.3 \%$ and $62.8 \%$ respectively (Figure 1 ). Median PFS was 12 months (range 2-32 months), with rates of $94.7 \%$ and $52 \%$ at 12 and 24 months respectively (Figure 2). The median overall survival times for $\mathrm{CN}$ and NCN groups were 19 and 10.5 months associated with high statistically significant difference $(P<0.001)$ (Figure 3) and the PFS of $\mathrm{CN}$ and NCN were 14 and 8.5 months with significant difference too $(P=0.046)$.

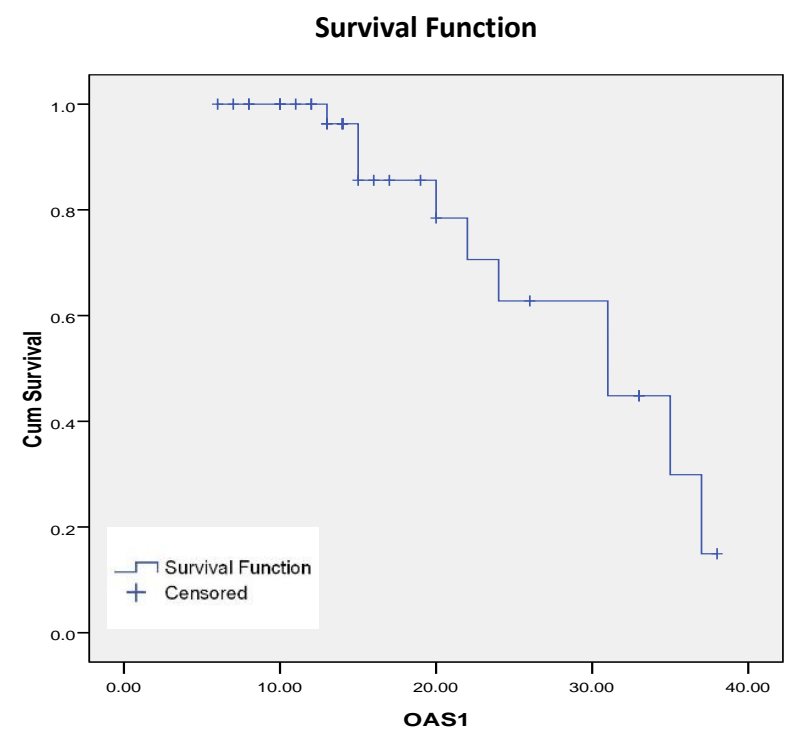

Figure 1. Kaplan-Meier curve for overall survival (OS)

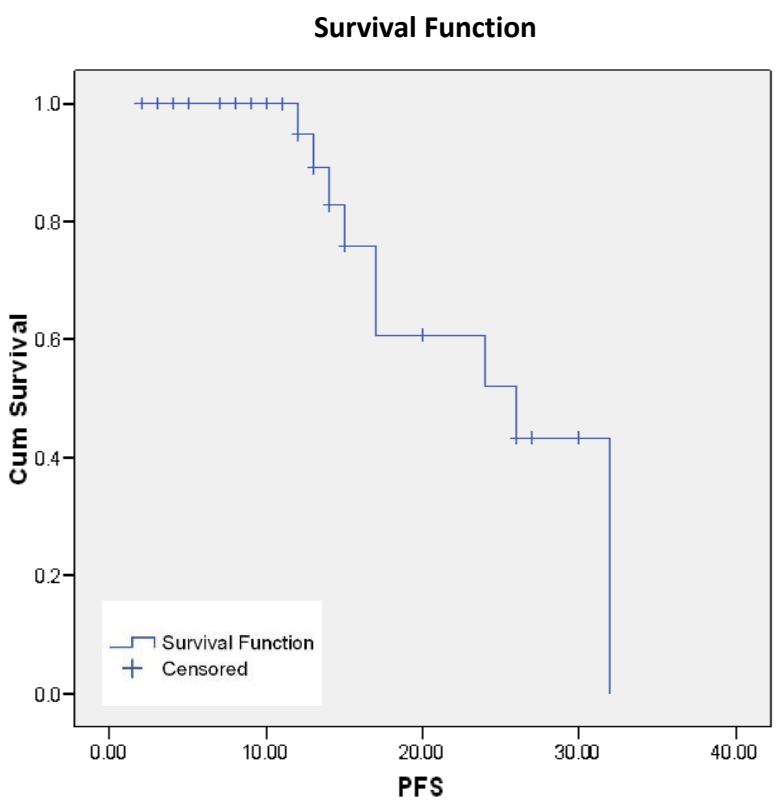

Figure 2. Kaplan-Meier curve for progression free survival

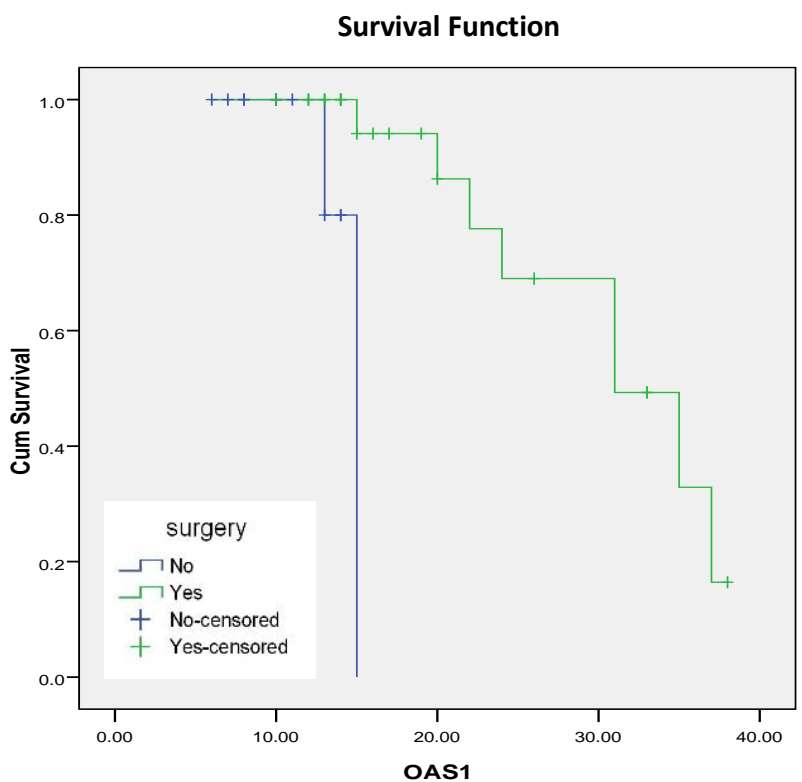

Figure 3. Comparison of overall survival (OS) between the cytoreductive nephrectomy (CN) and non-CN groups

Table 2. Response and fate of patients

\begin{tabular}{lcc}
\hline Outcome & $\begin{array}{c}\text { Cytoreductive } \\
\mathbf{N}(\%)\end{array}$ & $\begin{array}{c}\text { Non-cytoreductive } \\
\mathbf{N}(\%)\end{array}$ \\
\hline Response & $2(8)$ & $1(8.3)$ \\
PR & $9(36)$ & $1(8.3)$ \\
SD & $14(56)$ & $10(83.3)$ \\
PD & & \\
Fate & $8(32)$ & $2(16.7)$ \\
Alive & $17(68)$ & $10(83.3)$ \\
Dead &
\end{tabular}

PR: partial response, SD: stable disease, PD: progressed disease. 
The response rate was $35.1 \%$ (PR+SD) achieved in 13 patients, of which 11 of them were in the $\mathrm{CN}$ group but not significant statistically $(P=0.199) .10$ patients (27\%) out of 37 were alive at the end of the study, of which 8 of them (80\%) were in CN groups and also with no significance $(P=0.326)$ (Table 2$)$.

\section{Univariate analysis of prognostic factors}

On risk estimation, the overall survival showed improvement with significant difference with normal $\mathrm{Hg}$ level (median 18 months, $\mathrm{P}=0.001$ ), normal neutrophil count (median 20 months, $P<0.001$ ), normal platelet (median 15 months, $\mathrm{P}=0.013$ ), normal albumin (median 16 months, $\mathrm{P}=0.034$ ), negative lymph nodes (median 19 months, $\mathrm{P}=0.004$ ), absence of lung metastases (median 20 months, $\mathrm{P}=0.003$ ), absence of liver metastases (median 15 months, $\mathrm{P}=0.024$ ), and lower number of metastatic sites (median 32 months, $\mathrm{P}=0.002$ ) (Table 3).

The number of preoperative risk factors $<3$ was statistically high significant $(\mathrm{P}<0.000)$ predictors of OS.
Similarly, PFS showed improvement with a significant difference in the same previous factors with OS except for platelet which was not associated with a significant difference in survival (Table 3).

On univariate analysis of prognostic factors affecting survival in patients treated with $\mathrm{CN}$ and followed by TTs, the median survival was 23 months in patients with normal level of $\mathrm{Hg}$, which is more compared to patients with lower level of $\mathrm{Hg}$ that demonstrated the OS was only 14 months and was with significant difference $(P=0.012)$. On analysis according to the number of neutrophils, median survival was 24 months with normal count and 13 with elevated number which presented statistically high difference $(P<0.001)$. Also, the normal level of albumin was associated with better median survival of 20 months which was significantly longer than that of abnormal level (median 12.5 months; $\mathrm{P}=0.006$ ) (Table 4).

The number of metastatic sites $<3$ and number of risks $<3$ were associated with better survival (median 33 and 26 months respectively) than that with $\geq 3$ and both showed high statistical significance $(P<0.001)$ (Table 4).

Table 3. Prognostic factors in predicting OS and PFS of all patients

\begin{tabular}{|c|c|c|c|c|}
\hline Factors & $\begin{array}{l}\text { OS } \\
\text { median }\end{array}$ & $\mathbf{P}$ & $\begin{array}{l}\text { PFS } \\
\text { median } \\
(95 \% \mathrm{Cl})\end{array}$ & $\mathbf{P}$ \\
\hline Age & & 0.661 & & 0.637 \\
\hline$\leq 50$ & 14 & & 10 & \\
\hline$>50$ & 15 & & 12 & \\
\hline Sex & & 0.629 & & 0.960 \\
\hline Male & 14.5 & & 12.5 & \\
\hline Female & 14 & & 8 & \\
\hline PS & & 0.088 & & 0.104 \\
\hline 1 & 17 & & 14 & \\
\hline$>1$ & 14 & & 12 & \\
\hline Presentation & & 0.177 & & 0.205 \\
\hline Local & 17.5 & & 14 & \\
\hline Systemic & 14 & & 10 & \\
\hline $\mathrm{Hg}$ & & 0.001 & & 0.001 \\
\hline $\mathrm{N}$ & 18 & & 14.5 & \\
\hline$<\mathrm{N}$ & 12 & & 5 & \\
\hline Neutrophil & & $<0.001$ & & $<0.001$ \\
\hline $\mathrm{N}$ & 20 & & 15 & \\
\hline$>\mathrm{N}$ & 12 & & 4 & \\
\hline Plat & & 0.013 & & 0.082 \\
\hline $\mathrm{N}$ & 15 & & 13 & \\
\hline$>\mathrm{N}$ & 10 & & 5 & \\
\hline Alb & & 0.034 & & 0.006 \\
\hline $\mathrm{N}$ & 16 & & 13 & \\
\hline$<N$ & 11.5 & & 7.5 & \\
\hline LDH & & 0.300 & & 0.604 \\
\hline$<1.5$ ULN & 14 & & 13 & \\
\hline$>1.5$ ULN & 12 & & 10.5 & \\
\hline
\end{tabular}

\begin{tabular}{|c|c|c|c|c|}
\hline Factors & $\begin{array}{l}\text { OS } \\
\text { median }\end{array}$ & $\mathbf{P}$ & $\begin{array}{l}\text { PFS } \\
\text { median } \\
(95 \% \mathrm{Cl})\end{array}$ & $\mathbf{P}$ \\
\hline BMI & & 0.934 & & 0.788 \\
\hline $\mathrm{N}$ & 15 & & 12 & \\
\hline$a b n$ & 14 & & 11 & \\
\hline Side & & 0.515 & & 0.205 \\
\hline Rt & 13 & & 10.5 & \\
\hline $\mathrm{Lt}$ & 16 & & 12 & \\
\hline T stage & & 0.666 & & 0.948 \\
\hline 2 & 15 & & 11 & \\
\hline$>2$ & 14 & & 11 & \\
\hline N stage & & 0.004 & & 0.012 \\
\hline NO & 19 & & 14 & \\
\hline $\mathrm{N}+$ & 12.5 & & 7.5 & \\
\hline Bone mets & & 0.151 & & 0.118 \\
\hline No & 15.5 & & 12.5 & \\
\hline Yes & 14 & & 7 & \\
\hline Lung mets & & 0.003 & & 0.023 \\
\hline No & 20 & & 15 & \\
\hline Yes & 13 & & 8 & \\
\hline Liver mets & & 0.024 & & 0.005 \\
\hline No & 15 & & 13 & \\
\hline Yes & 12 & & 5 & \\
\hline No of met. Site & & 0.002 & & 0.001 \\
\hline$<3$ & 32 & & 25 & \\
\hline$\geq 3$ & 14 & & 9 & \\
\hline No of risk & & $<0.001$ & & $<0.001$ \\
\hline$<3$ & 26 & & 20 & \\
\hline$\geq 3$ & 13 & & 7 & \\
\hline
\end{tabular}

PS, performance status; Hg, hemoglobin; N, normal; plat, platelet; alb, albumin; LDH, lactate dehydrogenase; BMI, body mass index; abn, abnormal; Rt, right; Lt, left; $\mathrm{RH}$, rhabdoid; mets, metatstases; TTs, target therapies. 
Table 4. Univariate and multivariate analysis of preoperative factors in patients that received upfront CN followed by TTs

\begin{tabular}{|c|c|c|c|c|c|}
\hline Factors & MOS & $\begin{array}{l}\text { Univariate } \\
\text { analysis } \\
\mathrm{HR}(95 \% \mathrm{Cl})\end{array}$ & $\mathbf{P}$ & Multivariate & $\mathbf{P}$ \\
\hline \multicolumn{6}{|l|}{ Age } \\
\hline$\leq 50$ & 18.5 & $1.172(0.755-$ & 0.571 & & \\
\hline$>50$ & 19 & $1.819)$ & & & \\
\hline \multicolumn{6}{|l|}{ Sex } \\
\hline Male & 20 & $0.752(0.498-$ & 0.630 & & \\
\hline Female & 15 & $1.136)$ & & & \\
\hline \multicolumn{6}{|l|}{ PS } \\
\hline 1 & 20 & $1.315(0.816-$ & 0.431 & & \\
\hline$>1$ & 15.5 & $2.120)$ & & & \\
\hline \multicolumn{6}{|c|}{ Presentation } \\
\hline Local & 18 & $0.853(0.550$ & 0.503 & & \\
\hline Systemic & 13 & 1.324) & & & \\
\hline \multicolumn{6}{|c|}{18320953} \\
\hline $\mathrm{N}$ & 23 & 1.393(0.801- & 0.012 & $\begin{array}{l}1.832(0.953- \\
2.385)\end{array}$ & 0.172 \\
\hline$<\mathrm{N}$ & 14 & 2.423) & & & \\
\hline \multicolumn{6}{|l|}{ Neutrophil } \\
\hline$N$ & 24 & 1.449(0.857- & $<0.001$ & $\begin{array}{l}2.381(1.096- \\
4.513)\end{array}$ & 0.024 \\
\hline$>\mathrm{N}$ & 13 & $2.449)$ & & & \\
\hline \multicolumn{6}{|l|}{ Plat } \\
\hline $\mathrm{N}$ & 19.5 & $2.909(0.526-$ & 0.095 & & \\
\hline$>\mathrm{N}$ & 6 & $5.087)$ & & & \\
\hline \multicolumn{6}{|l|}{ Alb } \\
\hline $\mathrm{N}$ & 20 & 1.448(0.699- & 0.006 & $\begin{array}{l}0.985(0.113- \\
2163)\end{array}$ & 0.073 \\
\hline$<\mathrm{N}$ & 12.5 & $3.001)$ & & & \\
\hline \multicolumn{6}{|l|}{ LDH } \\
\hline$<1.5$ ULN & 20.5 & $1.333(0.430-$ & 0.635 & & \\
\hline$>1.5$ ULN & 18 & $4.134)$ & & & \\
\hline
\end{tabular}

\begin{tabular}{|c|c|c|c|c|c|}
\hline Factors & MOS & $\begin{array}{l}\text { Univariate } \\
\text { analysis } \\
\mathrm{HR}(95 \% \mathrm{Cl})\end{array}$ & $\mathbf{P}$ & Multivariate & $\mathbf{P}$ \\
\hline \multicolumn{6}{|l|}{ BMI } \\
\hline $\mathrm{N}$ & 19.5 & 1.419(0.618- & 0.933 & & \\
\hline$a b n$ & 14 & $3.259)$ & & & \\
\hline \multicolumn{6}{|l|}{ Side } \\
\hline Rt & 13 & 2.139(1.257- & 0.134 & & \\
\hline $\mathrm{Lt}$ & 20 & 4.529) & & & \\
\hline \multicolumn{6}{|l|}{ T stage } \\
\hline 2 & 19.5 & $1.300(0.802-$ & 0.443 & & \\
\hline$>2$ & 17.5 & $2.106)$ & & & \\
\hline \multicolumn{6}{|l|}{ N stage } \\
\hline NO & 20 & 1.684(1.020- & 0.245 & & \\
\hline $\mathrm{N}+$ & 15 & $2.780)$ & & & \\
\hline \multicolumn{6}{|c|}{ Bone mets } \\
\hline No & 22 & $0.869(0.527-$ & 0.369 & & \\
\hline Yes & 18.5 & $1.433)$ & & & \\
\hline \multicolumn{6}{|c|}{ Lung mets } \\
\hline No & 16.5 & 1.806(1.056- & 0.591 & & \\
\hline Yes & 8 & $3.090)$ & & & \\
\hline \multicolumn{6}{|c|}{ Liver mets } \\
\hline No & 10 & 1.103(0.612- & 0.283 & & \\
\hline Yes & 7.5 & $1.990)$ & & & \\
\hline \multicolumn{6}{|c|}{ No of met. } \\
\hline Site & & & 0.001 & $1.843(1.281-$ & 0.087 \\
\hline$<3$ & 33 & 1.519(1.044- & 0.001 & $3.421)$ & 0.081 \\
\hline$\geq 3$ & 14.5 & 2.209) & & & \\
\hline \multicolumn{6}{|c|}{ No of risk } \\
\hline$<3$ & 26 & $2.000(1.341-$ & $<0.001$ & $\begin{array}{l}2.364(1.641- \\
3.154)\end{array}$ & 0.009 \\
\hline$\geq 3$ & 14 & $2.984)$ & & & \\
\hline
\end{tabular}

PS: performance status, $\mathrm{Hg}$ : hemoglobin, N: normal, plat: platelet, alb: albumin, $\mathrm{LDH}$ : lactate dehydrogenase, BMI: body mass index, abn: abnormal, Rt: right, Lt: left, mets: metastasis.

\section{Multivariate analysis of prognostic factors}

On applying Cox regression on predictors associated with improvement in survival on univariate analysis, only normal count of neutrophil and no of risk factors $(\mathrm{P}=0.024$ and 0.009 , respectively) were considered as independent factors (Table 4).

\section{DISCUSSION}

Cytoreductive nephrectomy (CN) in mRCC was considered as part of treatment in combination with cytokines. But with target therapies (TTs), the role of CN remains questioned. The use of TTs as neoadjuvant to reduce tumor bulk allowed the $\mathrm{CN}$ to be proceeded [28]. The combination of TTs and $\mathrm{CN}$ was studied with the application of both in different sequences. So, neoadjuvant TTs followed by $\mathrm{CN}$ compared with $\mathrm{CN}$ alone resulted in an improvement of survival in combination over CN alone [29]. The same benefit was observed in patients treated with $\mathrm{CN}$ followed by interferon $\alpha$ in comparison to interferon $\alpha$ alone $[6,7]$.

Since the approval of TTs in treatment of $\mathrm{mRCC}$ achieved better clinical effect than immunotherapy, the role of $\mathrm{CN}$ declined [30]. But, $\mathrm{CN}$ remains associated with better survival [31], so, a controversy developed about the role of $\mathrm{CN}$ with TTs. There is a study which reported improved overall survival (OS) in patients with mRCC with TTs without CN [27]. However, there was a meta-analysis performed on large sample size in 2016, which registered that patients treated with upfront $\mathrm{CN}$ followed by TTs were associated with more than 2 folds prolonged OS compared with targeted therapy alone, but demonstrated no benefit in progression-free survival (PFS), nor increased risk of progression [32]. Same results were obtained by other studies [19, 24].

You et al. [33], reviewed 171 patients with mRCC and reported median OS 19.9 months in CN followed by TTs versus 11.7 months in TTs alone with significant difference $(P<0.001)$. Our results were in agreement with trials that recorded improved survival in $\mathrm{CN}+\mathrm{TTS}$ versus TTs alone, as the median survival was 19 months in $\mathrm{CN}$ group and 10.5 months in NCN group, with high significant difference $(p<0.001)$. Similarly, improvement in PFS was observed which was statistically significant $(p=0.046)$.

On the other hand, there were studies that did not demonstrate survival benefit from upfront $\mathrm{CN}[27,34]$. Phase III CARMENA trial reported a median survival of 18.4 months in patients treated with sunitinib versus 13.9 months in those treated with $\mathrm{CN}$ followed by 
sunitinib [27]. The limitation of CARMENA trial was in selecting candidates as it included patients only with good performance status (Eastern Cooperative Oncology Group 0 or 1 ) and excluded of patients with symptomatic or untreated brain metastases.

Despite improved survival in using upfront $\mathrm{CN}$ before $\mathrm{TT}$, there was a concern surrounding $\mathrm{CN}$ in identifying patients suitable for CN. Several studies have identified factors affecting survival after CN. The Memorial SloanKettering Cancer Center (MSKCC) prognostic score is useful in predicting patients with $\mathrm{mRCC}$ to get the benefit of $\mathrm{CN}$. These factors comprise of Karnofsky performance status, lactate dehydrogenase (LDH) level, hemoglobin level, serum calcium level, and prior nephrectomy [34].

Culp et al. (35) from the institutional RCC database of the University of Texas MD Anderson Cancer Center, identified seven pre-operative variables that permitted them to distinguish patients who were unlikely to benefit from $\mathrm{CN}$, including serum albumin and lactate dehydrogenase levels, clinical stage T3 or T4, symptoms caused by metastatic spread, liver metastasis and radiographic evidence of retroperitoneal or supradiaphragmatic adenopathy. Overall survival (OS) of patients who had four or more factors was not different from that of the cohort of patients with $\mathrm{mRCC}$ who received medical therapy alone.

From the recent analysis of the International Metastatic renal cell carcinoma Database Consortium (IMDC), Heng et al. [36] found that patients with estimated survival times $<12$ months, or having four or more risks may not benefit from $\mathrm{CN}$. Another large study included 645 patients demonstrated that performance status, calcium level, hemoglobin level, neutrophil count, platelet count, and time from diagnosis can predict survival [9]. Other adverse prognostic factors that were identified in other studies include multiple metastatic sites, sarcomatoid differentiation, elevated alkaline phosphatase, and thrombocytosis [37-39]. Some limitations of these trials are that inclusion criteria included patients treated with immunotherapy, and comparative groups were not performed.

In the present study, we tried to identify the effect of several prognostic factors on the survival of patients treated with $\mathrm{CN}$ upfront to TTs in comparison to patients that received only TTs. From univariate analysis we identified five variables determined before $\mathrm{CN}$ that had negative effect on survival, namely, lower hemoglobin level than normal $(P=0.012)$, high neutrophil count $(P<0.001)$ above normal, lower albumin level $(P=0.006)$, number of metastatic sites $\geq 3$ and number of risk factors $\geq 3$ associated with high significant $(P<0.001)$, but from multivariate analysis only neutrophil count and number of risk factors showed a significant effect on survival. This is in agreement with results detected by You et al. [33] and Hong et al. [32].
However, there were some limitations in our study. First, some prognostic factors such as calcium level were not recorded, and LDH level was not assessed in $75.7 \%$ of patients, sarcomatoid and rhabdoid differentiation was detected only in four patients so they were not analyzed with survival. Second, the retrospective analysis of data collected. Third, small sample size, and lastly, selection bias in determining which patients should be treated with upfront nephrectomy before targeted therapy.

\section{CONCLUSION}

Results of our study indicate that cytoreductive nephrectomy combined with target therapy has a significant overall survival advantage in patients with mRCC. However, the evidence is limited due to retrospective nature and small sample size of the present study. Although we detected some significant prognostic factors in predicting survival in patients that received $\mathrm{CN}$, further research should be made to predict factors to help the selection of patients. More large prospective studies are needed to prove these results.

\section{DECLARATIONS}

\section{Competing of Interest}

The authors declare that they have no competing interests.

\section{Acknowledgment}

The authors would like to thank all the authors of the studies cited in our study.

\section{REFERENCES}

1. Gupta K, Miller JD, Li JZ, Russell MW, Charbonneau C. Epidemiologic and socioeconomic burden of metastatic renal cell carcinoma (mRCC): a literature review. Cancer Treat Rev.2008 May;34(3):193-205.

2. Chow W, Dong L, Devesa S. Epidemiology and risk factors for kidney cancer. Nat Rev Urol. 2010 May;7(5):245-57.

3. Amal S, Hussein M, Nabiel N, Hoda B , and Hossam K. Cancer Incidence in Egypt: Results of the National Population-Based Cancer Registry Program. Journal of Cancer Epidemiology.2015; 2014: 1-18.

4. Ljungberg B, Campbell SC, Choi HY, Jacqmin D, Lee JE, Weikert S, et al. The epidemiology of renal cell carcinoma. Eur Urol. 2011 Oct;60(4):615-21

5. Cohen HT, McGovern FJ. Renal-cell carcinoma. N Engl J Med. 2005 Dec 8;353(23):2477-90.

6. Mickisch GH, Garin A, van Poppel $H$, et al. Radical nephrectomy plus interferon-alfa -based immunotherapy compared with interferon alfa 
alone in metastatic renal-cell carcinoma: a randomised trial. Lancet.2001; 358:966-970.

7. Flanigan RC, Salmon SE, Blumenstein BA, Bearman SI, Roy V, McGrath PC, etal.et al. Nephrectomy followed by interferon alfa-2b compared with interferon alfa-2b alone for metastatic renal-cell cancer. N Engl J Med 2001 Dec 6; 345:1655-59.

8. Flanigan RC, Mickisch G, Sylvester R, Tangen C, Van Poppel H, Crawford ED. Cytoreductive nephrectomy in patients with metastatic renal cancer: a combined analysis. J Urol. 2004 Mar;171(3):1071-6

9. Heng DY, Xie W, Regan MM, Warren MA, Golshayan $A R$, Sahi C,et al. Prognostic factors for over all survival in patients with metastatic renal cell carcinoma treated with vascular endothelial growth targeted-agents: results from large multicenter studu. J Clin Oncol. 2009 Dec 1;27(34):5794-9

10. Atkins $M$, Bukowski $R$, Euscudier $B$, Figlin $R, 4$ Hudes $G$, Kaelin $W$,et al. Innovations and challenges in renal cell cancer: summary statement from Third Cambridge Conference. Cancer. 2009 May 15; 115(10):2247-51.

11. Kenny $\mathrm{P}$, wood C. Integration of surgery and systemic therapy for renal cell carcinoma. Urol Clin North Am. 2012 May;39(2):211-31.

12. Motzer R, Hutson TE, Tomczak P, Michaelson MD, Bukowski RM, Rixe $\mathrm{O}$, et al. Sunitinib versus interferon alfa in metastatic renal-cell carcinoma. $\mathrm{N}$ Engl J Med. 2007 Jan 11;356(2):115-24.

13. Sternberg N, Davis I, Mardiak J, Szczylik C, Lee E, Wagstaff J, et al. Pazopanib in locally advanced or metastatic renal cell carcinoma: results of a randomized phase III trial. J Clin Oncol. 2010 Feb 20;28(6):1061-8.

14. Hudes G, Carducci M, Tomczak P, Dutcher J, Figlin R, Kapoor A, et al. Temsirolimus, interferon alfa, or both for advanced renal-cell carcinoma .N Engl J Med. 2007 May 31;356(22):2271-81.

15. Escudier B, Bellmunt J, Négrier S, Bajetta E, Melichar B, Bracarda S,et al. Phase III trial of bevacizumab plus interferon alfa-2a in patients with metastatic renal cell carcinoma (AVOREN): final analysis of overall survival. J Clin Oncol. 2010 May 1;28(13):2144-50.

16. Procopio G, Verzoni E, Bracarda S, Ricci S, Sacco C, Ridolfi $L$, et al. Sorafenib with interleukin-2 vs sorafenib alone in metastatic renal cell carcinoma: the ROSORC trial. Br J Cancer. 2011 Apr 12; 104(8): 1256-1261.

17. Jonasch E, Corn P, Pagliaro L, Warneke C, Johnson $M$, Tamboli $P$, et al. Upfront, randomized, phase 2 trial of sorafenib versus sorafenib and low-dose interferon alfa in patients with advanced renal cell carcinoma: clinical and biomarker analysis. Cancer. 2010 Jan 1;116(1): 57-65.
18. Motzer R, Escudier B, Oudard S, et al. Efficacy of everolimus in advanced renal cell carcinoma: a double-blind, randomised, placebo-controlled phase III trial. Lancet. 2008;372: 449-456.

19. 19. Petrelli $F$, Coinu $A$, Vavasorri I, Cabiddu $M$, Borgonovo K, Gilardi M, et al: Cytoreductive Nephrectomy in Metastatic Renal Cell Carcinoma Treated With Targeted Therapies: A Systematic Review With a Meta-Analysis. Clin Genitourin Cancer. 2016 Dec;14(6),:465-472.

20. Bhindi B, Habermann E, Mason R, Costello B, Pagliaro L, Thompson R, et al. Comparative Survival following Initial Cytoreductive Nephrectomy versus Initial Targeted Therapy for Metastatic Renal Cell Carcinoma. J Urol. 2018 Sep;200(3):528-34.

21. Russo $\mathrm{P}$, . Multi-modal treatment for metastatic renal cancer: the role of surgery. World J Urol. 2010Apr;28(3):295-301.

22. You D, Jeong IG, Ahn JH, Lee DH, Lee JL, Hong JH, et al. The value of cytoreductive nephrectomy for metastatic renal cell carcinoma in the era of targeted therapy. J Urol. 2011 Jan;185(1):54-9.

23. Choueiri $\mathrm{T}$, Xie W, Kollmannsberger $\mathrm{C}$, North $\mathrm{S}$, Knox J, Lampard JG, et al. The impact of cytoreductive nephrectomy on survival of patients with metastatic renal cell carcinoma receiving vascular endothelial growth factor targeted therapy. J Urol. 2011 Jan;185(1):60-6.

24. Yan S, Chun-Xia D, Wen Z, Yong-Kun Sun,1 Lin Yang,1 Cheng-Xu Cui,et al. Impact of Cytoreductive Nephrectomy on Survival in Patients with Metastatic Renal Cell Carcinoma Treated by Targeted Therapy. Chin Med J (Engl). 2016 Mar 5; 129(5): 530-535.

25. Bhindi B, Abel E, Albiges L, Bensalah K4, Boorjian SA5, Daneshmand S, et al. Systematic Review of the Role of Cytoreductive Nephrectomy in the Targeted Therapy Era and Beyond: An Individualized Approach to Metastatic Renal Cell Carcinoma. Eur Urol. 2019 Jan;75(1):111-128.

26. Richey S, Culp S, Jonasch E., Corn P, Pagliaro L, Tamboli $P$, et al. Outcome of patients with metastatic renal cell carcinoma treated with targeted therapy without cytoreductive nephrectomy. Ann Oncol. 2011 May; 22(5): 104853.

27. Méjean A, Escudier B, Thezenas S, et al: CARMENA: Cytoreductive nephrectomy followed by sunitinib versus sunitinib alone in metastatic renal cell carcinoma. 2018 ASCO Annual Meeting. Abstract LBA3. Presented June 3, 2018.

28. Cowey CL, Amin C, Pruthi RS, Wallen EM, Nielsen $\mathrm{ME}$, Grigson $\mathrm{G}$,et al. Neoadjuvant clinical trial with sorafenib for patients with stage II or higher renal cell carcinoma. J Clin Oncol. 2010 Mar 20;28(9):1502-7. 
29. Margulis V, Matin SF, Tannir N, Tamboli P, Swanson DA, Jonasch Eet al. Surgical morbidity associated with administration of targeted molecular therapies before cytoreductive nephrectomy or resection of locally recurrent renal cell carcinoma. J Urol. 2008 Jul;180(1):94-8.

30. Tsao CK, Small AC, Moshier EL, Gartrell B, Wisnivesky J, Sonpavde G, et al. Trends in the use of cytoreductive nephrectomy in the United States. Clin Genitourin Cancer; 2012sep: 10(3); 159-163.

31. Conti SL, Thomas IC, Hagedorn JC, Chung $\mathrm{BI}$, Chertow GM, Wagner TH, et al . Utilization of cytoreductive nephrectomy and patient survival in the targeted therapy era. Int J Cancer. 2014 May $1 ; 134(9): 2245-52$

32. Hong X, Li F, Tang K, Pang S1, Lin G1, Li Setal. Prognostic value of cytoreductive nephrectomy combined with targeted therapy for metastatic renal cell carcinoma: a meta-analysis. Int Urol Nephrol. 2016 Jun;48(6):967-75.

33. You D, Jeong I, Song C, Lee JL, Hong B, Hong J, etal. Analysis of pre- operative variables for identifying patients who might benefit from upfront cytoreductive nephrectomy for metastatic renal cell carcinoma in the targeted therapy era. Jap Clin Oncol. 2015 Jan;45(1):96-102 .

34. Motzer RJ, Bacik J, Mazumdar M. Prognostic factors for survival of patients with stage IV renal cell carcinoma: Memorial Sloan-Kettering Cancer Center experience. Clin Cancer Res. 2004Sep15;10(18) :6302-3.

35. Culp SH, Tannir NM, Abel EJ, Margulis V, Tamboli $P$, Matin SF,etal. Can we better select patients with metastatic renal cell carcinoma for cytoreductive nephrectomy? Cancer. 2010Jul15; 116(14): 337888.

36. Heng DY, Wells JC, Rini BI, Beuselinck B4, Lee JL5, Knox JJ, et al. Cytoreductive nephrectomy in patients with synchronous metastases from renal cell carcinoma: results from the international metastatic renal cell carcinoma database consortium. Eur Urol. 2014 Oct;66(4):704-10.

37. Cho KS, Choi YD, Kim SJ, kim Cl, Chung BH, Seong do $\mathrm{H}$, et al. A comprehensive prognostic stratification for patients with metastatic renal clear cell carcinoma. Yonsei Med J. 2008Jun1;49(3):451-458.

38. Muriel López $C$, Esteban E, Berros JP, Pardo $P$, Astudillo A, Izquierdo $M$, et al. Prognostic factors in patients with advanced renal cell carcinoma. Clin Genitourin Cancer. 2012 Dec;10(4):262-70.

39. Manola J, Royston P, Elson P, McCormack $J B$, Mazumdar $M$, Négrier $S$, et al. Prognostic model for survival in patients with metastatic renal cell carcinoma: results from the international kidney cancer working group. Clin Cancer Res. 2011 Aug 15;17(16):5443-50. 